\title{
Leopolis collection, Museum of Independence - wellspring of knowledge, state of research and recommendations
}

\author{
Jolanta Załęczny
}

dr hab. Jolanta Załęczny, prof. AfiB.

Academy of Finance and Business Vistula, Warsaw

Campus: Aleksander Gieysztor Academy in Pułtusk, Poland

e-mail: j.zaleczny@vistula.edu.pl

ORCID: 0000-0003-0615-410X

Muzeológia a kultúrne dedičstvo, 2021, 9:3:113-131

DOI: $10.46284 / \mathrm{mkd} .2021 .9 .3 .6$

Leopolis collection, Museum of independence - wellspring of knowledge, state of research and recommendations The Leopolis Collection (at the Museum of Independence) constitutes a valuable source of knowledge on the past of Lviv and its surroundings as well as the fate of the Polish people living there. Created in 1992 as a result of the efforts of Borderland circles, its contribution is used for research by museum specialists, professional historians and researchers of the Borderlands past. The artefacts, archival materials and publications collected there are made use of for preparing exhibitions, scholarly articles and monographs.

These valuable collections in relation to exhibitions are still awaiting a systematic study. Research undertaken so far has borne fruit in the form of valuable monographs and studies, but there are many valuable materials still waiting to be unearthed. For the purposes of accessing the museum materials the creation of a Leopolis Collection catalogue is necessary so that its contents can be more broadly made use of - both in historical research and that pertaining to museum-based studies.

Keywords: museum collection, Borderlands, Museum of Independence, Museum Studies, historical awareness, Lviv.

\section{Introduction}

The Eastern Borderlands occupy an unchangingly very important place in Polish history and culture. This is not exclusively a definition relating to a geographic area. It is a keyword for associations and meanings that are readable for those who understand the Polish presence in Lviv, Vilnius and Krzemieniec. Without this it is not possible to understand either the past or the present - nor is it possible to understand Polish culture.

Attempts at a contemporary definition of this concept have been undertaken by scholars representing various approaches to this very subject. ${ }^{1}$ Bolesław Hadaczek put forward this definition:

The Borderlands constitute a so-called umbrella-name (hypernym) embracing all the eastern lands of the first and second Polish Republics - and only these lands. This name, crystallising over centuries of national history, produced a spontaneous element, a one of its kind mental shortcut that is irreplaceable. ${ }^{2}$

\footnotetext{
${ }^{1}$ NICIEJA, Stanisław Sławomir. Legenda Kresów W schodnich Rzeczypospolitej, In: STAWARZ, Andrzej (ed.). Dz̧iedzictwo i pamię́ Kresów W schodnich Rzeczypospolitej. Materiały I Muzealnych Spotkań z Kresami. Warszawa: Muzeum Niepodległości, 2009, pp. 7-17.

${ }^{2}$ HADACZEK, Bolesław. Historia literatury kresowej. Szczecin: PoNaD, 2008, p. 376.
} 
The building of a particular place for the Borderlands in the historical consciousness of Poles was served by the legend of these lands created by writers and painters: "inspired by the authentic heroism of Borderlands communities, one stamped by history that became the legend of the Borderlands, a great and useful midwife to its history". ${ }^{3}$ World War II and the Yalta arrangements established immediately after it, determined the respective fates of the Eastern Borderlands of the Second Polish Republic and the Polish peoples living there. ${ }^{4}$ At that time, as would write Jerzy Janicki: "knowledge was disfigured, the accomplishments of culture, science and those of the country's history amputated, those that had been an integral part of Lviv for over 600 years". 5

Memory of the Borderlands, nonetheless, continues. We continue to remember, for example, the phenomenon of Lviv, its rich multicultural nature, one developing across the ages, creating an unrepeatable atmosphere. The society in this city created an unrepeatable climate of local patriotism, ${ }^{6}$ which bore fruit in an eternal commemoration of Lviv because the city had (and still has) it's heralds, ones proclaiming its fame, keeping watch over this memory and its past. Among those singing the praises of Lviv and the Borderlands and commemorating it were Wiktor Budzyński, Marian Hemar, Zbigniew Herbert, Jerzy Janicki, Stanisław Lem, Włada Majewska, Jerzy Michotek, Adam Zagajewski and Witold Szolginia. ${ }^{7}$ The figure of Szolginia (1923-1996), architect, writer, poet and graphic artist, in the opinion of many needs to be recalled for many reasons - this most renowned scholar of the Polish Lviv.

Zbigniew Herbert called him the "Guard of the City and its Graves". Jerzy Janicki wrote of him: "An absolute rabbi. Like a Pope, infallible in Lviv matters. A veritable judge in Leopoliensis conflicts in the area enclosed by the toll gates of Łyczaków and Zamarstyniv. The epitome of a Lviv citizen and an epitome of a Lyczaków citizen". ${ }^{8}$ For many years Witold Szolginia collected Lviv memorabilia and it is these that were to later give birth to the above-mentioned Leopolis Collection. The discovery of the "Lviv Atlantis" and lost roots constituted a splendid mission in his life and a testament for future generations of Poles who were no longer familiar with the Polish Lviv. ${ }^{9}$

This was an exceptional city in the annals of Poland as well as in Europe - it is here that throughout several centuries were to cross the influences of many cultures, religions and traditions shaping this metropolis of a unique nature. This particularity of Lviv explains perfectly the creation of "semper fidelis" cultural relics tied to the city, the heart of the collection, constituting one of the most important elements in the holdings of the Museum of Independence in Warsaw. It is difficult not to have the impression that without Polish

\footnotetext{
${ }^{3}$ PRÓCHNIK, Adam. Obrona Lwowa, Zamość: Zygmunt Pomarański i Spółka, 1919, p. 5.

${ }^{4}$ NICIEJA, Stanisław Sławomir. Pojałtański symot miast przesiedlonych na proylkładzie Lwowa, In: NICIEJA, Stanisław Sławomir (ed.). Jalta z perspektyny pótwiecza. Materiaty z konferenciji naukowej zorganizowanej przę Instytut Historii Uniwersytetu Opolskiego w dniach 25-26 października 1994 r., Opole: Instytut Historii Uniwersytetu Opolskiego, 1995, pp. 143-157.

${ }^{5}$ JANICKI, Jerzy. Ni ma jak Lwón: krótki przewodnik po Lwowie, Warszawa: Oficyna Literatów „Rój”, 1990, p. 32.

${ }^{6}$ NICIEJA, Stanisław Sławomir. Kresowa Atlantyda. Historia i mitologia miast kresonych. Lwón, Stanisławón, Tarnopol, Brzeżany, Borystaw, Opole: Wydawnictwo MS, 2012, pp. 67-68.

${ }^{7}$ These are but several names of those connected to Lviv. The authors of the Borderlands Encyclopaedia mentioned eighty-eight names of those active in the present day at scholarly, cultural and political institutions; KAROLCZUKKĘDZIERSKA, Monika (ed.) Encyklopedia Kresów, Kraków: Wydawnictwo Kluszczyński, 2004, p. 249.

${ }^{8}$ KACZOROWSKI, Andrzej. „Pamiéć, skarb tutaçy...”” (Witold Szolginia), In: SZOLGINIA, Witold. Tamten Lwów, t. 8: Arcylwowianie, Wrocław: Oficyna Wydawnicza Sudety, 1997, p. 201.

${ }^{9}$ KACZOROWSKI, Andrzej. „Pamié, skarb tułacsy....”... p. 202.
} 
consciousness of the borderlands a Polish identity would be incomplete, one devoid of roots. All of us in Poland therefore come from the Borderlands. Further, we have this awareness, when analysing the history of the Polish nation and the biography of renowned figures and events from the past. That is why the collection and research of memorabilia is so important, so integral to the Leopolis Collection at the Museum.

\section{Museum collection}

In the professional literature under the concept of collection a defined whole is understood, one of selected components that are usually at a similar level and high value. The essence of a collection therefore is the collection of so-called mobile artefacts according to an earlier established key: artistic, cultural, historical, scientific and cognitive or other. ${ }^{10}$

The International Committee for Collecting, COMCOL, defines collections of objects as dynamic actors to fulfil an institution's mission. In the process of building collections, contacts with collectors (both individual and institutions) are extremely important, because they contribute to the creation and development of museum collections. ${ }^{11}$

Collectors become active participants in museum activities, focusing on ideas and objects important to the institution and creating it. They share their collections with the museum and they become participants in its activities. ${ }^{12}$ Collections donated by collectors create or expand museum collections. In this process, it is important to evaluate the materials. According to Markus Walz, one should be guided by historical, artistic, research (scientific) and social significance. Moreover, from the point of view of the museum, the origin, authenticity, category of rarity or representativeness, physical condition, and connection with the mission of the institution are important. Therefore, a multifaceted examination of the collections donated by collectors is indispensable. One should also consider the emotional value of the object and the value assigned to it over time, which is important in shaping memory. ${ }^{13}$

The function of the museum is to preserve the traces of the past in order to pass them on to future generations. ${ }^{14}$ Creating a collection depends on the financial capacity of the institution, and hence the free donation of collections by donors is immensely valuable. Creating a collection is one of the basic tasks of museums included in their definition. It is governed by

\footnotetext{
${ }^{10}$ KOWALSKI, Wojciech. GWOŹDZIEWICZ-MATAN, Paulina. Kolekcja. In: ZEIDLER, Kamila (ed.). Leksykon prawa ochrony zabytków. 100 podstawowych poję́, Warszawa: Wydawnictwo C.H.Beck, 2010, pp. 115-116. Please see: ZALASIŃSKA Katarzyna, Muzealia, zbiory, eksponaty, kolekecja muzealna oraz zasoby muzeum - pojecia podstawowe w muzealnictwie. In: STEC, Piotr. P.P. MANIURKA, Piotr, Paweł (eds.). Kolekcje i zbiory muzealne. Problematyka prawna, Opole: Wydawnictwo Wydziału Teologicznego Uniwersytetu Opolskiego, 2015, pp. 8-15.

${ }^{11}$ MENSCH, Leontine Meijer, MENSCH, Peter. Participative strategies in collecting the present. Introduction. In: Participative strategies in collecting the present, MENSCH, Leontine Meijer, TIETMEYER, Elisabeth (eds.), Berlin, Berliner Blatter, 2013, pp. 8-9; LAI, Ying Ying. Museum Collection Re-defined. A Case Study of TOGO Rural Art Museum, Taiwan. In: Muzeológia a kultúrne dedičstvo, 2019, vol. 7, no. 1, pp. 75-76; CORRAL, Oscar,N.avajas. Ecomuseums in Spain: an analysis of their characteristics and typologies. In: Muzeológia a kulturne dedičstvo, 2019, vol. 7, no. 1, p.19.

${ }^{12}$ SIMON, Nina. The participatory museum, Santa Cruz: CA. Museum 2.0, 2010, p. 187.

${ }^{13}$ WALZ, Markus. The selection of cultural assets between research and plebiscite. Five museological points dealing with "collecting 2.0”. In: MENSCH, Leontine Meijer, TIETMEYER, Elisabeth (eds.). Participative strategies in collecting the present. Berlin: Berliner Blatter, pp. 124-126. Please see: ASSMAN, Jan. Pamiéć kulturowa. In: Pamiéć zbiorowa i kulturowa. W spótczesna perspektywa niemiecka, SARYUSZ-WOLSKA, Magdalena (ed.), Kraków: Universitas, 2009, pp. 59-100; CHUNG, Yun Shun Susie. Museum Communication, Exhibition Policy and Plan: The Field Museum as a Case Study. In: Muzeológia a kultúrne dedičstvo, 2019, vol. 7, no. 2, pp. 7-21.

${ }^{14}$ VERGO, Peter. Milczacy obiek.t. In: Muz̧eum sz̧tuki. Antologia, POPCZYK, Maria (ed.), Kraków: Universitas, 2005, p. 313.
} 
legal regulations. Detailed rules are contained in the ordinances of the director of the facility.

According to the statute of July 23, 2003 (Dz. U. 2003, no 162, pos. 1568) on the preservation and conservation of relics, a collection is a store of objects collected and organised according to the concept of those responsible for its creation. The collections stored by private individuals end up in museums on the basis of civil law contracts, which result in transferring the ownership of objects (contract of sale, exchange, donation) to the museum. Such stores are materials constituting collections that can be given to the museum as a deposit or loan. ${ }^{15}$

The requirement over time is not only to create museum collections, but also to analyse the process of their development and use in the museum's work and in scientific research.

\section{History of the Leopolis Collection}

The Leopolis Collection arose as an initiative of representatives from the Warsaw Delegation of Towaraystwo Miłośników Lwowa [Aficionados of Lviv Association]. ${ }^{16}$ Towards the end of 1992 Aleksandra Garlicka and Jerzy Janicki submitted an official letter on this matter to the director of the Museum of Independence in Warsaw. Indeed, it was good fortune that these two sides found common ground and room for coming to an agreement. In this way the mission of the museum has been realised, one whose sense of identity is to fulfil relevant social tasks.

On the decision of the Institute director, Dr Andrzej Stawarz, on December 18, 1992 the Kolekcja Leopolis [Leopolis Collection] at the Muzeum Niepodległości [Museum of Independence] in Warsaw was established. In the preamble the particular place of Lviv and the history of Poland and Poles was underscored, with a commitment to "the systematic collection of historical and museum materials, or material and non-material traces of the past that convey the truth and legend on Lviv". ${ }^{17}$ According to the founders intentions the establishment of the Leopolis Collection, being a reference to the tradition of the pre-war Towaryystwo Mitosników Przeszłości Lwowa [Lviv Aficionados of the Past Association], was to serve towards the preservation of memory and the dissemination of historical heritage. In so doing, it constitutes an integral part of the Museum collections, whereby the institute director is responsible for its oversight and, in turn, designates a curator for the Collection.

A systematic enlargement of the Collection was planned by means of the purchase, transfer and donation from individuals and institutions, and objects with their genesis in exchanges between museums and by means of collection competitions etc. Monies for the purchase of collections were to be accrued on the Museum's sub-account, the so-called Collection Fund. Regardless of the nature and place of storage (Creation of Collections Section, Iconography Section, Chief Stock Taker Section, Museum Library) the collections were to constitute a selfsufficient whole.

Members of the Aficionados of Lviv Association, Warsaw Delegation and representatives of the Museum on January 8, 1993 established a Collection Council, being a think-tank of

${ }^{15}$ GWOŹDZIEWICZ-MATAN, Paulina. GREDKA-LIGARSKA, Iwona. Przekasywanie kolekecji na rzeecz, muzeów na podstawie czynności prawnych intervivos oraz mortis causa; http://cenezcenne.pl/wp-content/uploads/2020/01/2019-3-4GREDKA-GWOZDZIEWICZ.pdf [access: 28.12.2020]; LADYKA, Natalia. Pozyskiwanie zbiorów muzealnych, In: ABC zarzqdzania kolekecja muzealnq, Warszawa: NIMOZ, 2014, no 3, pp. 12-21.

16 The Aficionados of Lviv Association was established in Wrocław and registered there on September 22, 1988. The Warsaw Delegation was registered on December 17, 1988. WIÓRKIEWICZ, Helena. Kolekcja Leopolis Muzeum Niepodlegtości w Warsqawie. In: 10 lat Muzeum Niepodlegtości w Warszawie 1990-2000. Ksiega Pamiatkowa, Warszawa: Muzeum Niepodległości, 2000, p. 127.

${ }^{17}$ Directive number 22, December 18, 1992 of the Museum of Independence Director in Warsaw, regarding the establishment of the Leopolis Collection. 
the Museum director in matters related to the Collection. It constituted eighteen people, ${ }^{18}$ for whom the Lviv subject matter was very familiar. Jerzy Janicki was elected chair (radio and television script writer, playwright and journalist). For the purposes of liaison with the Museum the following Collection curators were designated: Ryszard Brykowski, Aleksandra Garlicka and Tadeusz Rudkowski. Those present passed a resolution for the Council regulations and principles of managing the Collection fund. ${ }^{19}$ Helena Wiórkiewicz was elected curator for the Leopolis Collection at the Museum and Witold Szolginia designed the Collection logo.

The "Lviv Rare Book" exhibition initiated the functioning of the Leopolis Collection on May 5, 1993. This was an occasion to interest a broader group of those interested in Lviv subject matter as well as a means of strengthening collaboration with those from Lviv. This was the time in fact when the first donations came (about 300 exhibits given by six donors) to the Collection. Further, the Museum coffers began filling, thanks to which it was possible to buy valuable exhibits such as, for example, the purchase in 1993 at the UNICUM auction house the painting by Marcel Harasimowicz "A Panorama of Lwów”, 1914.

\section{Contents of the Leopolis Collection}

The Leopolis Collection has its roots in the hobbies of those from the Borderlands. For them, collecting was - as would write Janusz Wasyłkowski - "a substitute for unfulfilled love, professional ambition not realised, an escape into the world of fantasy mixed with an audacious imagination and even an escape from nightmares that would nag even when awake". ${ }^{20}$

To the museum's collection there were sent photographs, postcards and various mementos from families that came from Lviv. Borderlands organisations were often intermediaries, inspiring the members to comb their family archives. The list of donors is very large indeed. In the first year of the Collection the Museum received in sum 560 objects from twelve donors and, in addition, bought fifty such. The first donors were: Witold Szolginia (Warsaw), Ewa Jęczalik (Wrocław), Barbara Mroczek (Bytom), Artur Leinwand (Warsaw), Stanisław Ożóg (Warsaw), Władysława Lesnobrodzka-Włoczewska (Warsaw), Leszek Fabrycki (Warsaw), Krzysztof Lubziński (Dębica), Zofia Rysiówna-Hanuszkiewicz (Warsaw), Janusz Wasylkowski (Warsaw), Wanda Straszyńska (Warsaw) and Irena Szenderowicz (Great Britain).

To take the first five years of the Collection, seventy donors gave around 1700 objects. ${ }^{21}$ At present the Collection numbers already over 5000 objects donated by over 100 donors living in twenty-five cities in Poland and abroad. ${ }^{22}$ The Leopolis Collection contains realia, postcards, photographs, archival materials and family mementos. These document the annals of Lviv during the partition and that of the Second Polish Republic as well as being witness to the life of Lviv families. The materials given are of a sentimental value for donors, but from

\footnotetext{
${ }^{18}$ Józef Bobrowski, Ryszard Brykowski, Wojciech Dzieduszycki, Aleksandra Garlicka, Marian Garlicki, Jerzy Janicki, Jerzy Kołaczkowski, Zofia Kurzowa, Artur Leinwand, Janusz Majewski, Krystyna Maszumańska-Nazar, Stanisław Sławomir Nicieja, Tadeusz Rudkowski, Witold Szolginia, Janusz Wasylkowski, Jerzy Wegierski, Władysław Zalewski, Mirosław Żuławski, Magdalena Bajer, Aleksandra Leinwand, Bożena Krupska, Piotr Piniński.

${ }_{19}$ These matters were regulated by Directive number 17, November 19, 1993 of the Museum of Independence Director in Warsaw, regarding the utilisation of the Leopolis Collection Fund.

${ }^{20}$ WASYLKOWSKI, Janusz. Notatki kolekcjonera. In: Kresy Wschodnie Rzecsypospolitej. Ziemia i ludzie, Warszawa: Muzeum Niepodległości, 1997, b.p.

${ }^{21}$ A full list of names is given in WIÓRKIEWICZ, Helena. Kolek.cja Leopolis Muzeum Niepodległości w Warszawie, „Niepodległość i Pamięć” 1999, no 1 (14), pp. 224-225.

${ }^{22}$ WIÓRKIEWICZ, Helena. II Muzealne Spotkania z Kresami. Z prac nad organizacją konferencji i przygotowaniem publikacji. In: Rocznike Kresowy, 2017, no 3, p. 146.
} 
the Museum's point of view they are a uniquely valuable source of knowledge on Lviv and its residents, allowing us to "construct a valuable whole - a picture of the life of the city's residents - one that is no more". ${ }^{23}$

The materials collected over time relate first and foremost to the history of Lviv during the partitions and the Second Polish Republic, while a small section of materials relates to SouthEast Małopolska and the East-Northern Borderlands.

In the Collection itself it is possible to identify several thematic groups. First, there are photographs - individual, group, documentary and so-called tableaux. Next, there are postcards - family documents as well as those of community life and those from publishing houses. Last, there are iconographies of Lviv - drawings with views of the city from the turn of the twentieth century, photographs and postcards published by the known Lviv company Książnica-Atlas in 1937-1939, photographs taken by Michał Stanisław Progulski and engravings by Ludwik Tyrowicz. Of particular value is the oil painting by Stanisław Kaczor Batowski Reduta Najmłodszych (1938) and the cycle of seventeen watercolours by Tadeusz Pobóg-Rossowski. Moreover, the Collection boasts thirty-one contemporary watercolours by Zbigniew Gumienny from the period 1976-1991, drawings by Władysław Szczepański and watercolours by the Ukrainian painter Aleksander Franko.

Another section of the Collection contains plans, guides and vade mecums of Lviv and the Lviv province. In this respect, one of the collections of interest relates to paraphernalia and documents of community life, press publications, medals and memorabilia related to World War I and battles over Lviv in 1918-1920. From the period of World War II (1939-1944) there are amateur photographs, testaments, ID cards, Polish, Ukrainian and German press publications, iconographic materials, archival materials, cartographic materials and printed matter presenting community and business life in Lviv. In addition, documentation has survived from production plants such as the power plant at Persenkówce and the Miejskie Zakłady Elektryczne (City Power Plant), as well as documentation of the Targi Wschodnie (Eastern Fair).

A major part of the collections contains materials presenting the work of institutions, schools and universities as well as community organisations: Lviv Polytechnic and the University of Jan Kazimierz in Lviv, or Towaryystwo Popierania Turystyki (Tourism Promotion Association), for example. In this respect the most valuable are objects relating to the Lviv University: unique, decorative graduation diplomas of congratulations related to the 250th anniversary of the universities founding, invitations and the diplomas documenting international Lviv contacts, the professorial gown and headwear of Professor Michał Stanisław Progulski (1874-1941), doctoral and masters diplomas, student record books, student IDs, student records, printed lecture programmes and transcripts of speeches by rectors. Among the memorabilia is the official record book of doctoral supervisions with 385 alphabetical records of doctoral students for the period from October 30, 1891 to December 1, 1900. From the Lviv Polytechnic there have been preserved several documents for a number of students from the period 1901-1940 (graduation diplomas, student record books, student IDs, university matriculation files) and photographs (tableaux) of graduates. In addition, the Collection has received a considerable number of materials relating to primary and high school education in Lviv (photographs, badges and documents), which constitute a valuable source of knowledge on the history of schools and the history of its graduates and teachers.

\footnotetext{
${ }^{23}$ SKOCZEK, Tadeusz. ŻYWEK, Lukasz. Kolekcja Leopolis w zbiorach Muzeum Niepodległości, In: Niepodległość
} i Pamiéć, 2014, no 3-4 (47-48), p. 287. 
Also, pre-war Lviv radio circles present a very valuable set of formal documentation: Wesola Lwowska Fala (Merry Waves of Lviv) in the period 1933-1939, then during World War II presented as the artistic group Czotówka Teatralna Wojska Polskiego Nr 1 "Lwowska Fala" (Polish Army Theatre Aces No.1 "Waves of Lviv"), which was collected by its members Kazimierz Jan Wajda “Szczepko”, Henryk Vogelfänger “Tońko”, Włada Majewska and Józef Wieszczek. These materials constitute varia (photographs, invitations, announcements and programmes, press clippings with reviews) from the period 1934-1945 and eight volumes of printed monologues, dialogues, sketches and songs of the Lwowska Fala from November 1939 to December 1946 (mainly by Wiktor Budzyński), printed programmes and announcements of performances and concerts, photographs of individual artists and the entire group, six albums of commemorative books of travel and performances containing entries by the audience, reviews, photographs and letters.

For the researcher-biographer, of particular interest are the private collections of several Lviv families. These contain photographs, personal documents (birth certificates, certificates of christenings and weddings, diplomas, work certificates, securities, business cards etc.) as well as various objects from family collections. It is on this basis that it is possible to recreate a picture of community, political and cultural life in Lviv and the part particular families played in it. Among the well-known Lviv families whose collections were donated to the Museum Collection, it is worth noting the following families: Drexler, Gorczyński, Progulski, Pasławski, Skierski, Zalewski, Jurkowski, Rybak, Klimowicz, Złotnicki, Zych and Zbrożk. These materials are both family memorabilia and a witness to the lives of the city and its people, among them those of artists and thinkers.

Many of these materials therefore are related to the very lives of people who left their own stamp on the history of Lviv and that of its surrounding lands. In this context, it is worth noting Ludwik Zalewski and his pastry shop at ul. Akademicka, Władysław Zych who fought for Lviv in 1919, and later on the Silesia insurgent Józef Mieczysław Michał Pawluk, who for his entire life was tied to Lviv (fought for Lviv, later Lviv official). In addition, of particular value are the photographs and documents relating to the education and professional work of the Lviv ophthalmologist Teodor Karol Bałłaban. Family mementos have also been preserved of the Lviv Gorczyński doctors. Among the family memorabilia belonging to Stanisław Fiałkiewicz, director of the tax office in Lviv, apart from the photographs and documents that have been preserved there are also fragments of a porcelain dowry set from his wife (Kazimierz Lewicki, Lviv). There are also many precious mementos related to the Klimowicz family and two generations of collections from the Mroczek family related to the pastry chef Zalewski as well as documents and photographs outlining the history of four generations of the Skierski family.

The Collection also has many objects of everyday use from Lviv shops, production plants and homes (devices for whipping cream, a tin from Ludwik Zalewski's pastry company, a doctor's thermometer from the Piotr Mikolasch apothecary, a clothes hanger from the Lviv shop at ul. Sykstuska and a coloured mug for drinking mineral water in Truskawiec).

Thus both materials from families and personal mementos from individuals constitute a jigsaw puzzle by which to recreate the history of the city's citizens, those who made the city a special place.

In addition, materials have been added to the Collection that paint a picture of other parts of the eastern lands of the former Second Polish Republic. Among these are engravings (mostly 
the lithographs by A. Misierowicz based on the drawings of N. Orda), drawings, watercolours and postcards. Deserving particular note are the Wolyn and Vilnius photograph albums - there are also guides, vade mecums and some issues of Borderlands newspapers.

Complimentary to these Museum materials is a library collection of books relating according to subject and place to Lviv as well as a collection of Borderlands journals (including Lviv). In the Museum of Independence library there is a collection of contemporary journals on the Eastern Borderlands of the former Second Polish Republic, pre-1939 borders, which in the main come from donations. In addition, it has been possible to obtain Borderlands press items published in London: Biuletyn Kola Lwowian (Lviv Circles Bulletin), Kwartalnik Kresowy (Borderlands Quarterly), Biuletyn Zwiqzku Ziem Wschodnich RP (Polish Eastern Lands Association Bulletin) and Zeszyty Lwowskie (Lviv Gazette). Among the titles published in Poland in the museum there are, among others, the following: Semper Fidelis, Cracovia-Leopolis, Biuletyn Informacyjny Oddziatu Stolecznego TMLiKPW (TMLiKPW Warsaw Delegation Information Bulletin), Rocznik Lwowski (Lviv Annual), Przeglad Wschodni (Eastern Review), Wotyń Bližej (Wołyń Eye), Biuletyn Informacyjny TMLiKPW Oddział Kraków' (TMLiKPW Kraków Delegation Information Bulletin) and Biuletyn Informacyjny Ogólnopolskiego Oddziału Żołnierzy AK Obszaru Lwowskiego im. Orląt Lwowskich (ŚZŻAK Home Army “Lviv Green Eagles” National Delegation Information Bulletin).

\section{Exhibitions created from the Leopolis Collection}

The main motive for the creation of the Leopolis Collection was to document the life of Lviv and the presence of Poles in its history. The collected materials were made use of, among others, in the exhibitions of the Museum of Independence. For every exhibit on the Borderlands a thorough search was essential of the Museum resources and relevant institutions in Poland and abroad. The Collection becomes therefore the first and often most important area of research.

Exhibitions that can be classified as of the Borderlands are those Museum exhibitions where exhibits are presented from the Borderlands or such whose main subject is the history and culture of the Borderlands. In this respect, Magdalena Sacha identified three categories of Borderlands exhibitions, depending on the presence of a particular subject matter within them: exhibitions presenting the heritage of the Borderlands as the main motif, those with a Borderlands theme as an element of exhibitions from its own collection and, last, exhibitions aiming at preserving memory on the history of the Borderlands (in particular communities that were resettled). ${ }^{24}$

As previously mentioned, the first exhibition on the subject of Lviv, entitled Lviv Rare Books, was opened on May 5, 1993 (open until June 15). It was created with the use of the private collections of Jerzy Janicki, Witold Szolginia and Janusz Wasylkowski. These were memorabilia (over 600 exhibits) documenting family life and various aspects of community life in Lviv. Witold Szolginia presented interesting collections illustrating the life of scholars and culture in Lviv from the middle of the nineteenth century up to the outbreak of World War II, materials documenting the work of the artistic group Wesola Lwowska Fala. In the last week of the exhibition an additional section was organised, containing sixty-five donations presented to the

\footnotetext{
${ }^{24}$ It is difficult to relate this division of exhibitions prepared at the Museum of Independence on the basis of the Leopolis Collection, though the author places these exhibitions in category two. SACHA, Magdalena Izabella. Los niewidoczny? Kresy i kresowianie jako temat ekspozycji muzealnych po 1989 roku. In: Muzealnictwo, 2019, no 60, p. 117.
} 
Leopolis Collection. Also the Lviv Rare Book exhibition had a pamphlet with a text by Witold Szolginia, Wyznanie (Credo), where he went on to describe his collections as "a chip of that long gone time, magical catalyst of memory". ${ }^{25}$

From May 27 to July 10, 1994 a large exhibition was arranged in the Museum of donations and materials purchased from the Leopolis Collection. On account of the limited exhibition space, only the most valuable and most interesting exhibits were presented - in all 424 artefacts were shown. The exhibition was divided into two parts. The first was an unrepeatable sentimental voyage to pre-war Lviv and the other - entitled Oczyma szarego człowieka - illustrated contemporary Lviv on the drawings of Władysław Szczepański.

The exhibition, Dary i nabytki Leopolis (Donations and Procurements), Collection Museum of Independence in Warsaw, was accompanied by the Weekend Lwowski (June 25-26) event, where a meeting with Witold Szolginia and a session of films on Lviv took place. ${ }^{26}$ The closing of the exhibition was honoured with a meeting with Janusz Wasylkowski.

The yearly exhibitions organised on Lviv became a Museum tradition. In 1995 - on the occasion of the 100th anniversary of the Towaryystwo Ludoznawcze (Folklore Association) in Lviv - an exhibition was prepared at the Museum of Independence, We Lwowie przed stu laty. U źródeł Polskiego Towarzystwa Ludoznawczego (In Lviv a Hundred Years Ago. The Provenance of the Polish Folklore Association). This exhibition was of an historic and ethnographic nature, presenting Lviv in the nineteenth and twentieth centuries and providing a reminder of the most splendid of the work of the above association (1895-1905) and one of the main research areas - Huculszczyzna. Therefore many examples of its folk arts were shown, both from the Museum collections and private ones. Moreover, other museums in Poland and the Lwowska Galeria Obrazón (Lviv Gallery of Paintings) lent exhibits. It should be added that this exhibition received a distinction at the national competition for Najważniejsze Wydarzenie Muzealne Roku 1995 (The Most Important Museum Event of 1995).

The exhibition was complemented by accompanying events. Apart from the traditional Weekend Lwowski with Szolginia and Wasylkowski, two lectures were organised, one by Zygmunt Kłodnicki on Lviv during the workings of the Polskie Towarsystwo Ludoznawcze and the other by Stefan Rosiński on Huculszczyźna. The ceremonial closing of the exhibition (January 1996) was honoured by Janusz Wasylkowski's lecture on Lviv carnivals and a performance by a band from Lviv.

From September 17, 1997 to January 18, 1998 at the Museum of Independence the public were able to view the exhibition Kresy Wschodnie Rzeczypospolitej. Ziemia $i$ ludzie (The Eastern Borderlands of Poland. Land and People), which was initiated by Janusz Wasylkowski (Lviv Institute). At the exhibition, in terms of history, ethnography and geography, the history of the Borderlands from the end of the eighteenth century up to 1939 was illustrated. As Andrzej Stawarz emphasised, the aim of the exhibition was to leave guests after they had left the Museum "with the conviction that the Eastern Borderlands were not a mythical land of otherworldly exoticism, but as an important - perhaps discovered anew - element of Polish culture, one deep in our hearts and minds". ${ }^{27}$

The exhibition was divided into three parts. In the first, based on maps, engravings and

\footnotetext{
${ }^{25}$ WIÓRKIEWICZ, Helena. Witold Szolginia 1923-1996. In: Niepodległość i Pamiéć, 1996, no 2 (6), p. 214.

${ }^{26}$ As part of the Weekend Lwowski the following films were shown: „Wszystko dla Orląt” (reż. Z. Kowalewski), „Włóczęgi” (reż. M. Waszyński), „Mój Lwów (reż. W. Gołaszewski), „Będzie lepiej-z udziałem Szczepcia i Tońcia”. ${ }^{27}$ STAWARZ, Andrzej. Słowo wstępne. In: Kresy W schodnie Rzecsypospolitej. Ziemi i ludz̨ie, Warszawa: Muzeum Niepodległości, 1997, b.p.
} 
paintings, the Borderlands were presented in a historical perspective. The second, main part, presented Borderlands provinces of the Second Polish Republic through their history, relics and particular features. The last part took place on September 17 and related to the final period of the Borderlands in the Polish Republic. ${ }^{28}$

In all, 1216 objects from thirty-six museums, libraries and archives as well as private collections were presented. ${ }^{29}$ It is worth adding that this was the first such in Poland devoted entirely to the Eastern Borderlands. Its initiator and organiser was Helena Wiórkiewicz and the architectural as well as artistic design belonged to Marta Kodym. The jury of the national competition recognised the attributes of the exhibition and awarded it Najważniejsze Wydarzenie Murealne 1997, (The Most Important Museum Event of 1997), whereupon its creators received an award..$^{30}$

Materials making up the Leopolis Collection and memorabilia from Marian Przyślewicz served to make up an exhibition of posters, W osiemdziesiata rocznice obrony Lwowa 1918-1919. Dokumenty $i$ materialy (The 80th Anniversary of the Defence of Lviv 1918-1919. Documents and Materials), November 20-29, 1998. This was the first time some documents and announcements were presented - those issued by various organisations during the Battle of Lviv in Druki Wojskowe (Army Journal) November 1-22, 1918).

In subsequent years subject matter related to the Borderlands (including Lviv) appeared sporadically. In this context, it is worth noting the exhibition Kresy w fotografii Henryka Poddelbskiego (Borderlands in the Photography of Henryk Poddębski), January 2011, where Lviv accents also appeared. Here, there was also a lecture by Małgorzata Florczak (PAN Institute of the Arts) and Professor Jan Lewandowski (UMSC).

The most recent exhibition, Kresy i bezkeresy w zbiorach Muzeum Niepodlegtości (Borderlands and Open Frontiers in Museum of Independence Collections), was prepared in 2020, where several aspects of the subject Miasto Semper Fidelis (heroic battles in defence of Lviv 1918-1919) were presented: Lwów sie bawi (Party Time in Lviv) - Lviv culture, first and foremost a part devoted to the Wesola Lwowska Fala as well as iconography related to the cultural life of Lviv and places connected to this. Further, there was a discussion on Miedzy duchem a materiq... (Between the Spiritual and the Material) - the workings of Lviv higher education institutions (University of Jan Kazimierz, Lviv Polytechnic, Academy of Overseas Trade, Academy of Veterinary Medicine) and that of Pieśn dzisiaj niech miłowana - zprzewonnych łąk duszy zwiana (Let Us Love Song Today - On Meadows Scented in Spirit Lay); society and its people on the example of Lviv families. ${ }^{31}$

All the exhibitions mentioned above are examples of the use of collections that make up the materials of the Leopolis Collection for Museum purposes. This, it can be said, is a splendid means of popularising knowledge on the Borderlands, helping people become familiar with the Polish history of these lands and a means of reminding us all about the people that come to make up history as we know it in that part of the world.

\footnotetext{
${ }^{28}$ WIÓRKIEWICZ, Helena. Wystawa. In: Kresy Wschodnie Rzecryppospolitej. Ziemia i ludzie, Warszawa: Muzeum Niepodległości, 1997, b.p.

${ }^{29}$ This was made up of 51 oil paintings, 123 watercolours, drawings, lithographs, 26 posters and announcements, 269 photographs, 263 postcards, 25 maps and plans, 190 ethnographic relics, 148 various prints and 100 other objects. ${ }^{30}$ WIÓRKIEWICZ, Helena. Kresy Wschodnie Rzeczypospolitej. Ziemia i ludzie Wystawa w Muzeum Niepodległości w Warszawie. In: Niepodlegtosś i Pamiéć,1999, no 1 (14), pp. 247-264.

${ }^{31}$ BAKALA, Krzysztof. Kresy i bęlkesy w zbiorach Muzeum Niepodległości w Warszanie, Warszawa: Muzeum Niepodległości, 2020, pp. 2-4.
} 
Apart from exhibitions on the Borderlands that have been organised at the Museum, the materials from the Leopolis Collection were presented in other exhibition spaces and devoted to various events and people tied to Lviv itself. As an example of how such collections may be used is the exhibition The Leopolis Collection, organised by the Museum of Independence in the Polish Radio building in Warsaw and in the accompanying conference Polskie Radio na Kresach Wschodnich II Rzeczypospolitej (Polish Radio in the Eastern Borderlands, II Polish Republic) organised by the Archives of Polish Radio in November 2013. ${ }^{32}$ This was on the occasion of the eighty-fifth anniversary of the establishment of Polish Radio in Vilnius and the eightieth anniversary of the first radio programme, Wesola Lwowska Fala, as well as the seventy-fifth anniversary of the establishment of Polish Radio in Baranowicze.

It is worth noting in this place also that both the work related to the collection and the preparation of materials as well as their dissemination to the wider public at organised exhibitions has gained acceptance by the broader public. By force of the resolution of the Foundation Board, Pomoc Polakom na Wschodzie (Help for Poles in the East), on September 29, 2004, the Collection curator Helena Wiórkiewicz was awarded the Honorary Medal of the Foundation, Meritus Patriae. In 2005 the chairman of the Warsaw Delegation of TMLiKPW, Father Janusz Popławski, awarded Museum Director Andrzej Stawarz the Złota Odznaka Towaraystwa Miłośnikón Lwowa (Lviv Aficionados Association Gold Medal), showing appreciation for his work for the preservation of memory on Polish culture in the Borderlands. On the occasion of the Jubilee, Thirty years of the Warsaw Delegation, Aficionados of Lviv and South-Eastern Borderlands Association, on December 16, 2018 the Museum was honoured with a medal and received gratitude for "preserving and managing the Leopolis Collection".

\section{Research conducted, making use of the Collection}

It is difficult not to agree with the view of Lukasz Żywek, who emphasises that:

Behind every, even ordinary object, there is a history that is worth preserving. Lviv memorabilia are subject to the wear and tear of time and in several years without professional conservation and preservation they may be beyond our retrieval. Thus in finding their place at the Leopolis Collection, Museum of Independence in Warsaw, they come under professional conservation and lend themselves to increasing our knowledge on this important city for Poland. ${ }^{33}$

The Leopolis Collection - this treasure trove of Borderlands memorabilia - also constitutes a continuing goldmine of knowledge on the history of the Borderlands. It has been made use of many a time, though as yet insufficiently. For the most part, the specialists at the Museum of Independence access these materials, initiating research for the purposes of exhibitions or so as to lay the groundwork for scholarly articles or papers at conferences on Borderlands subject matter.

\footnotetext{
${ }^{32}$ The Polish Academy of Sciences and the Institute of Political Studies were co-organisers of the conference under the aegis of the Honourable Jan Dworak, Chair of the National Radio and Television Board and Longin Komołowski, Chair of the Association for a United Poland. The conference was hosted by the Ministry of Foreign Affairs, Department of Cooperation with Polonia and Poles with TVP Historia as media patron.

${ }_{33}$ ZYWEK, Lukasz. Kolekcja Leopolis Muzeum Niepodległości w Warszawie, In: Lwowski Biuletyn Informacyjny, 2015, no 1(74), p. 14.
} 
Many such texts are published in Museum journals such as Niepodlegtość i Pamięć(Independence and Memory) and Rocznik Kresowy (Borderlands Annual). In this context it is worth mentioning that three special issues of the former, Niepodleglości Pamięć 'Kresy Wschodnie Rzeczypospolitej' (Independence and Memory - 'Polish Eastern Borderlands'), have been published. They are, respectively: W obronie polskości (1999) (In Defence of Polishness), Historia i pamię́c Lwowa (2006) (History and Memory of Lviv) and Wotyn: historia i dziedzictwo (2008) (Wołyn: History and Heritage). The single-subject issues had the aim of making readers familiar on a broader scale with the relevant topic. It should also be noted that in the issue devoted to the history of Lviv a text by Mirosława Pałaszewska was devoted to memorabilia left by Władysław Zych. ${ }^{34}$

Helena Wiórkiewicz has written articles devoted to memorabilia belonging to the Drexler family. On the basis of collected materials she completed research and published in the journal Niepodlegtość i Pamię́ a study on the history of the Drexler family and their contribution to the development of Polish culture in the Borderlands. ${ }^{35}$ Wiórkiewicz also presented this research at the II Muzealne Spotkania z Kresami (2nd Museum Convention) in 2011, where her paper was published in post-conference materials. ${ }^{36}$

In this context the journal Rocznik Kresowy (published by the Museum of Independence since 2015) has provided a relatively new base for the scholarly exchange of views - a journal devoted to the preservation of the memory of lands lost as a result of political or military decisions. ${ }^{37}$ It is in this journal that articles are published as a result of research conducted at the Leopolis Collection ${ }^{38}$ as well as those discussing specific objects such as, for example, the drawings of Tadeusz Pobóg-Rossowski ${ }^{39}$ or Stownik gwary lwowskiej (Dictionary of Lviv Dialect) by Kazimierz Schleyen. ${ }^{40}$

General research at the Leopolis Collection in addition allows for the preparation of interesting papers presented during research conferences - scholarly work that has been and continues to be undertaken at the Museum. This not only constitutes a so-called popularisation of stored materials from the Leopolis Collection, but also a dissemination of knowledge on the contribution of Polish citizens in the annals of Borderlands cities and circles.

As already mentioned, research on memorabilia connected with the artists of the Lwowska Fala has been undertaken by Lukasz Żywek, who created a portrait of Włada Majewska ${ }^{41}$ in a paper at the XVI Międynarodowe Sympozjum Biografistyki Polonijnej, Lwowianie w świecie (16th International Symposium on Polonia Biography Studies: Lviv People Across the World), Warsaw,

\footnotetext{
${ }^{34}$ PALASZEWSKA, Mirosława. Pamiątki po Władysławie Zychu. In: Niepodległość i Pamiéć, 2006, no 3 (24), pp. $347-362$.

${ }^{35}$ WIÓRKIEWICZ, Helena. Pamiątki lwowskiej rodziny Drexlerów w zbiorach Muzeum Niepodległości w Warszawie : dar Jadwigi Kern-Bałaty. In: Niepodległość i Pamiéć, 2013, no 3-4 (43-44), pp. 305-367.

${ }^{36}$ WIÓRKIEWICZ, Helena. Pamiątki lwowskiej rodziny Drexlerów w zbiorach Muzeum Niepodległości w Warszawie. In: Driedzictwo ipamiéć Kresów Wschodnich Rzecryppospolitej. II Muzealne Spotkania z Kresami, Warszawa, Wydawnictwo Muzeum Niepodległości, 2017, pp. 243-299.

${ }^{37}$ SKOCZEK, Tadeusz. Zamiast wstępu. In: Rocznik Kresony, 2015, no 1, p. 5.

${ }^{38}$ ZALECZNY, Jolanta. Smakowanie Lwowa. Ludwik i Władysław Zalewscy oraz ich cukiernia. In: Rocznik Kresony, 2016, no 2, pp. 103-130.

${ }^{39}$ ŚWIERZEWSKA, Olga.,,... krocząc wśród pocisków i ognia”. Lwów 1918-1919 w obrazkach Tadeusza Pobóg-Rossowskiego. In: Rocznik Kresony, 2018, no 4, pp. 93-160. The text was previously published in the journal Niepodlegtość i Pamiéć, 1998, no 4 (13), pp. 113-136.

${ }^{40}$ BĄKAŁA, Krzysztof. Słownik gwary lwowskiej Kazimierza Roberta Schleyena ze zbiorów Muzeum Niepodległości. In: Rocznik Kresony, 2018, no 4, pp. 173-187.

${ }^{41}$ ŻYWEK, Łukasz. Włada Majewska - muza „Lwowskiej Fali”. In: GMITRUK, Janusz. JYDYCKI, Zbigniew. SKOCZEK, Tadeusz (eds.). Lwowianie w świecie. Warszawa: Fundacja Polonia Semper Fidelis, 2017, pp. 199-207.
} 
November 17, 2017. This author also addressed the work of Lwowska Fala in emigration with the aid of extant comprehensive collections, presenting our research at the conference Polskie wychodźstwo i jego prazyczyny podczas II wojny światowej i po jej zakończeniu (Polish Emigration and Its Causes During WWII and Thereafter) organised by Światowa Rada Badań nad Poloniq i Instytut Nauk Historycznych (Polonia World Research Council and Institute of Historical Sciences), Cardinal Stefan Wyszyński University in Warsaw on November 24-25, 2018. In addition, based on the materials at the Leopolis Collection, the paper Kresowe biografie wpisane w wojne 1939 roku (Borderlands Biographies Written in War 1939) was presented at the conference A jednak wojna... Rok 1939 na Kresach W schodnich $i$ Zachodnich (War in Fact... The Year 1939 in Eastern and Western Borderlands) at the Górnośląski Museum in Bytom on November 22, 2019.42

Various materials relating to correspondence constitute another highly interesting research resource at the Leopolis Collection. It should be noted that letters are no easy matter when it comes to researching them, first and foremost in respect to the difficulty of deciphering handwriting. This may indeed explain the relatively small number of research works on correspondence itself. It is possible, nonetheless, to note that Lukasz Żywek conducted research on a letter from Kazimierz Bartel to Rudolf Kaczorowski, ${ }^{43}$ whereas the present author conducted a study of correspondence between Florentyna Skierska and Zofia Romanowiczówna. ${ }^{44}$

Moreover, there are also texts discussing the history of those people connected with Lviv or, more widely, the Borderlands. ${ }^{45}$ It should also not be forgotten that photographs from the Leopolis Collection are made use of as an important graphic material. ${ }^{46}$ This collection is also utilised by researchers beyond the Museum itself, though there the research is as a rule of a complementary nature, whereby the relevant materials are not referred to either in footnotes or the relevant bibliography.

\section{Research Recommendations}

The Leopolis Collection has yet to see a research project commensurate with its importance and breadth of materials. To date the most comprehensive has been conducted by Helena Wiórkiewicz in relation to publications on the history of the Collection and some of its elements. In this respect memorabilia connected to the Wesola Lwowska Fala have seen the most such, documenting among others, books of commemoration that were coined by Witold Szolginia as "companions of Lviv pilgrimage". ${ }^{47}$ All the materials preserved in the Museum relating to the Lwowska Fala constitute - according to Wiórkiewicz - important documentation of the

\footnotetext{
42 ZALECZNY, Jolanta. Kresowe biografie wpisane w wojnę 1939 roku, In: FIC, Maciej. LUSEK, Joanna. ZAŁECZNY, Jolanta (eds.). A jednak wojna... Rok 1939 na Kresach W schodnich i Zachodnich. Bytom-Warszawa-Katowice: Muzeum Górnośląskiego, Muzeum Niepodległości, Uniwersytet Śląski, 2020, pp. 232-253.

${ }^{43}$ ZZYWEK, Lukasz. Kolekcja Leopolis. List prof. Kazimierza Bartla do Rudolfa Kaczorowskiego, Lwów, 6.01.1922. In: Niepodlegtość i Pamię́, 2016, no 4, pp. 239-243.

${ }^{44}$ ZAŁECZNY, Jolanta. Kobiece troski, pasje i marzenia w listach Florentyny Skierskiej (1839-1890) do przyjaciółki Zofii Romanowiczówny. In: KITA, Jarosław. KORYBUT-MARCINIAK, Maria (eds.). Życie prywatne Polaków w XIX wieku. t. VII. Prywatne światy zamknięte w listach. Lódź-Olsztyn: Wydawnictwo Uniwersytetu Lódzkiego, 2018, pp. 149-163.

${ }^{45}$ PALASZEWSKA, Mirosława. Kolekcja generała Romana Abrahama (1891-1976) w Muzeum Niepodległości. In: Niepodlegtość i Pamię́, 2009, no 16/2 (30), pp. 319-344.

${ }^{46}$ GARLICKA, Aleksandra. „Ex orientelux” kultura i nauka we Lwowie 1772-1939. Szkic. In: Niepodległośc i Pamiéc, 2006, no 13/3 (24), pp. 71-92.

${ }^{47}$ WIÓRKIEWICZ, Helena. „Księgi pielgrzymstwa lwowskiego” w zbiorach Kolekcji Leopolis Muzeum Niepodległości w Warszawie. In: Dziedzictwo i pamię́ Kresów Wschodnich Rzeczypospolitej. Materialy I Muzealnych Spotkań z. Kresami, Warszawa: Muzeum Niepodległości, 2009, pp. 145-165..
} 
life of Lviv and its people in respect to the theatre and the city's history, which are exceptionally valuable both in terms of exhibits and research. ${ }^{48}$

Collections relating to particular individuals and families have been the focus of considerable research on the part of this author. Apart from the above-mentioned correspondence of Florentyna Skierska and Zofia Romanowiczówna, the Klimowicz ${ }^{49}$ and Zalewski ${ }^{50}$ families and their memorabilia, the contribution of Mieczysław Mroczek ${ }^{51}$ as well as the work and poetry of Maria Mazurek have all seen studies from the above author. ${ }^{52}$ The research in this area has also borne fruit in radio programmes on the Borderlands, to take the example of the Lviv family pastry chefs presented in the Christmas radio broadcast Święta $w$ Jedynce. This particular formal popularisation of such materials would appear to be particularly important for building a picture of the Borderlands and Lviv in the minds of contemporary generations of Poles.

Yet still more exceptionally valuable materials await research and organisation - for example, there are studies deservedly awaited that will address the history of Lviv families (among others Jurkowski, Skierski, Górzyński, Złotnicki and Klimowicz). Moreover, of particular interest are archival materials bringing into relief education in the city, including memorabilia of teachers such as Oktawia Grzaski ${ }^{33}$ and the Wowkun sisters Franciszka and Ludwika. Further, there are many documents from the Lviv Polytechnic and the University of Jan Kazimierz that bring into light much valuable information on scholarly activities. There are also exhibits with their genesis in Lviv institutions and shops (tins, product containers, bottles) increasing our knowledge on the everyday life of this Borderlands city. Last, there are numerous works of art deserving of wider interest both in respect to their subjects and the artists themselves.

In reminding of the process of establishing Museum collections it is worth noting one more matter concerning the nature of organisation itself. Lukasz Żywek, author of an invaluable study on the people of Vilnius in the collections of the Museum, suggested establishing - on the basis of the Leopolis Collection - one large Borderlands Collection into which all other stores and materials related to the Eastern Borderlands of the Polish Republic be added, which at present constitute separate parts (Krzemieniec Collection, Vilnius Varia). ${ }^{54}$

Notwithstanding how Museum specialists will view the functioning of the Leopolis Collection, it is appropriate to call for a further systematic enlargement of materials gained from donors or archives. This in turn requires making contact with Lviv individuals and their heirs. ${ }^{55}$

\footnotetext{
${ }^{48}$ WIÓRKIEWICZ, Helena. Kolekcja Leopolis Muzeum Niepodległości w Warszawie. In: Niepodległość i Pamiéć, 1999, no 1 (14), pp. 235-242.

49 ZAŁECZZNY, Jolanta. Pamiątki rodziny Klimowiczów w Kolekcji Leopolis Muzeum Niepodległości w Warszawie. In: Rocznike Muzeum Górnoślaskiego w Bytomiu. 2016, no 10, pp. 101-114.

${ }^{50}$ ZALECZNY, Jolanta. Smakowanie Lwowa. Ludwik i Władysław Zalewscy i ich cukiernia. In: Rocznik Kresony, 2016, no 3, pp. 103-130.

51 ZAŁĘCZNY, Jolanta. Szkic do lwowskich losów rodziny Mroczków. In: Rocznike Lwowski, 2017, pp. 105-147; eadem, Mieczysław Mroczek (1889-1939) - zwykły obrońca niezwykłego miasta. In: KOSESKI, Adam. SKOCZEK, Tadeusz. ZAŁECZNY, Jolanta (eds.). W drugim sžeregu. Bohaterowie walk o niepodlegtość, Warszawa-Pułtusk: Wydawnictwo Muzeum Niepodległości, Akademia Humanistyczna w Pułtusku, 2019, pp. 57-68.

${ }^{52}$ ZAŁECZNY, Jolanta. Maria Mazurkówna z Lwowa - sekretarka GTOZ, opiekunka przyrody i miłośniczka historii. In: Wrockawskie Studia Wschodnie, 2020, no 24, pp. 221-236.

${ }^{53}$ Her recollections were published in 1999: Oktawia Grząska, Byłam wię́niarką NKWD, Warszawa: Wydawnictwo Muzeum Niepodległości 1999.

${ }^{54}$ ŻYWEK, Łukasz. Vilniana w zbiorach Muzeum Niepodległości w Warsqawie, Warszawa: Wydawnictwo Muzeum Niepodległości, 2017, p. 11.

55 Please see: GLOWACKA-GRAJPER, Małgorzata. Transmisja pamieci. Działacze „sfery pamięi” i przekaz o Kresach Wschodnich we wspótczesnej Polsce, Warszawa: Wydawnictwa Uniwersytetu Warszawskiego, 2016.
} 
Therefore of extreme use would be the close and long-term planning of cooperation with Borderlands associations, which - in bringing together Polish citizens from the Borderlands and their families - would constitute a natural partner in Museum activities. Journals published by such an organisation (i.e. Cracovia Leopolis) would make for an ideal platform to present information and establish contact with those from the Borderlands.

Also of vital interest, would be a closer cooperation with museums that concern themselves with the Borderlands, which there is no lack of. ${ }^{56}$ No doubt many specialists in these institutions would more than happily take advantage of the possibility of using the Leopolis Collection in their work on the materials at hand. It would appear therefore that its contents are still known only to those at the Museum of Independence, for though we live in an age of the almighty and omnipresent Internet, knowledge on the resources stored in Museum so-called dungeons is by no means widespread. Perhaps therefore it is worth creating, based on the project of storing and digitalising data on the heritage of the Eastern Borderlands (www.kresyMuseum.pl), an accessible Internet catalogue of the Leopolis Collection for everyone - though this particular enterprise requires additional funding.

Taking into account therefore that in Poland as such as many as 4.3 to 4.6 million people over eighteen admit to having Borderlands roots, ${ }^{57}$ popularising the subject of the Borderlands would appear to be exceptionally important. All the more so as in the case of the Borderlands of vital concern is "the social transfer of cultural memory in relation to this part of society that has not experienced the loss of their so-called family land and indeed, in relation to subsequent generations". ${ }^{58}$ It is of particular consequence therefore to aim towards the preservation of memory in families becoming an element of the cultural collective of society and, in the process, the building of its historical awareness. This is possible thanks to the work of "museums as institutions that come to crystallise the memory of their communities and that of building the identity of groups and the social transfer of knowledge". 59

The very fact of museums undertaking work for the purposes of the preservation of memory and dissemination of knowledge on Borderlands heritage proves just how important a role is played by such institutions. It is also worth noting in this context that the Borderlands heritage is not only one of Poland itself, but also that of Europe at large. To take but an example, the history of Borderlands peoples stripped of their country in the east and transported to new terrains in the west is at the same time the history of ex-patriots and settlers and, in its own way, iconic of the twentieth century.

The exhibitions organised on the basis of Borderlands collections and scholarly activities at conferences or published texts are responsible for the dissemination of knowledge on the history of these people in the Borderlands and lend themselves to the building of a collective memory in society, which is so important for the shaping of the awareness of Polish citizens.

\footnotetext{
${ }^{56}$ Across Poland in 2019 there were three museums that carried the expression Borderlands in their name: The Museum of Lviv and South-Eastern Borderlands in Kuklówka Radziejowicka (registered in 2011), The Museum of Borderlands and Ostrowska Lands in Ostrów Mazowiecka (2013) and the Museum of Borderlands in Lubaczów (1958; as the Museum of Borderlands from 2004). At present at the National Museum in Lublin a new section is to be established - the Museum of Lands of the Former Polish Republic. Moreover, many such institutions, though, in their collections have Borderlands memorabilia that is presented at exhibitions.

${ }^{57}$ CBOS, Kresowe korzenie Polaków, p. 2, online: https://www.cbos.pl/SPISKOM.POL/2012/K_050_12.PDF [access: 28.12.2020].

${ }^{58}$ SACHA, Magdalena Izabella. Los niewidoczny? Kresy i keresowianie..., p. 116.

${ }^{59}$ Ibidem, p. 116.
} 
There is still one more aspect of such ventures which needs to be raised. All of the above allows those from the Borderlands to face their past and come to terms with their own personal losses related to their former cultural "alma mater". It is thanks to this that those of the Borderlands can set themselves free from their traumatic past ${ }^{60}$ and come to experience the most beautiful and least troublesome forms of "owning their own patch" - that of "being their own masters in our collective memory, in literature and in museums". ${ }^{61}$

\section{References}

ASSMAN, Jan (2009). Pamięć kulturowa. In: SARYUSZ-WOLSKA, Magdalena (ed.). Pamięć zbiorowa i kulturowa. W spótczesna perspektywa niemiecka. Kraków: Universitas, pp. 59-100.

BAzKA£A, Krzysztof (2018). Słownik gwary lwowskiej Kazimierza Roberta Schleyena ze zbiorów Muzeum Niepodległości. In: Rocznike Kresowy, no 4, pp. 173-187. ISSN 2391-6435.

BĄKA£A, Krzysztof (2020). Kresy $i$ bezkresy w zbiorach Muzeum Niepodległości w Warszawie, Warszawa: Muzeum Niepodległości. ISBN 978-83-65439-63-5.

BUGAJEWSKI, Maciej. SARYUSZ-WOLSKA, Magdalena (2014). password: Praca pamięci. In: SARYUSZ-WOLSKA, Magdalena. TRABA, Robert (eds.). Modi memorandi. Leksykeon kultury pamieci, Warszawa: Wydawnictwo Naukowe Scholar, pp. 393-395. ISBN 978-8373836-61-7

CBOS, Kresowe korzenie Polaków, p. 2, online: https://www.cbos.pl/SPISKOM. POL/2012/K_050_12.PDF

CORRAL, Oscar,N.avajas. Ecomuseums in Spain: an analysis of their characteristics and typologies. In: Muzeológia a kultúrne dedičstvo, 2019, vol. 7, no. 1, pp. 7-22. ISSN 1339-2204.

CHUNG, Yun Shun Susie. Museum Communication, Exhibition Policy and Plan: The Field Museum as a Case Study. In: Mureológia a kultúrne dedičstvo, 2019, vol. 7, no. 2, pp. 7-21. ISSN 1339-2204.

GARLICKA, Aleksandra (2006). „Ex oriente lux” kultura i nauka we Lwowie 1772-1939. Szkic. In: Niepodleglość i Pamiéć, no 13/3 (24), pp. 71-92. ISSN 1427-1443.

GLOWACKA-GRAJPER, Małgorzata (2016). Transmisja pamieci. Driatacze „sfery pamieci” i pržekaz o Kresach W schodnich we wspótczesnej Polsce. Warszawa: Wydawnictwa Uniwersytetu Warszawskiego. ISBN 978-83-23525-87-5.

GRZĄSKA, Oktawia (1999). Byłam wieźniarka NKWD. Warszawa: Wydawnictwo Muzeum Niepodległości. ISBN 83-87516-14-7.

GWOŹDZIEWICZ-MATAN, Paulina, GREDKA-LIGARSKA, Iwona (2020). Przekazywanie kolekecji na rzecz. muzeón na podstawie caynności prawnych inter vivos oraz mortis causa; http:// cenezcenne.pl/wp-content/uploads/2020/01/2019-3-4-GREDKA-GWOZDZIEWICZ. pdf

HADACZEK, Bolesław (2008). Historia literatury kresowej. Szczecin: PoNaD. ISBN 97883-2421602-4.

\footnotetext{
${ }^{60}$ BUGAJEWSKI, Maciej. SARYUSZ-WOLSKA, Magdalena. password: Praca pamięci. In: SARYUSZ-WOLSKA, Magdalena. TRABA, Robert (eds.). Modi memorandi. Leksykon kultury pamieci, Warszawa: Wydawnictwo Naukowe Scholar, 2014, pp. 393-395.

${ }^{61}$ SACHA, Magdalena. Fantomowe dziedzictwo? Różnice w muzealnej prezentacji dziedzictwa niemieckiego wschodu oraz polskich kresów - próba diagnozy,. In: Rocznik Antropologii Historii, 2016, VI (9), p. 147.
} 
JANICKI, Jerzy (1990). Ni ma jak Lwów: krótki przewodnik po Lwowie. Warszawa: Oficyna Literatów „Rój”. ISBN 83-85049-16-9.

KACZOROWSKI, Andrzej (1997). „Pamięć, skarb tułaczy...” (Witold Szolginia). In: SZOLGINIA, Witold (ed.). Tamten Lwów, t. 8: Arcylwowianie, Wrocław: Oficyna Wydawnicza Sudety.

KAROLCZUK-KĘDZIERSKA, Monika (red.). (2004). Encyklopedia Kresów, Kraków: Wydawnictwo Kluszczyński. ISBN 83-89550-93-8.

KOWALSKI, Wojciech. GWOŹDZIEWICZ-MATAN, Paulina (2010). Kolekcja. In: ZEIDLER, Kamila (eds.). Leksykon prawa ochrony zabytków. 100 podstawowych pojeć. Warszawa: Wydawnictwo C.H.Beck. ISBN 97883-255-0824-1.

LAI, Ying Ying (2019). Museum Collection Re-defined. A Case Study of TOGO Rural Art Museum, Taiwan. In: Muzeológia a kultúrne dedičstvo, 2019, vol. 7, no. 1, pp. 75-82. ISSN 1339-2204.

ŁADYKA, Natalia (2014). Pozyskiwanie zbiorów muzealnych, In: ABC zarzqdzania kolekcja muzealna, Warszawa: NIMOZ no 3, pp. 12-21. ISBN 83-93691-25-7.

MENSCH, Leontine Meijer, MENSCH, Peter (2013). Participative strategies in collecting the present. Introduction. In: MENSCH, Leontine Meijer, TIETMEYER, Elisabeth (eds.). Participative strategies in collecting the present. Berlin: Berliner Blatter, pp. 8-14.

NICIEJA, Stanisław Sławomir (1995). Pojałtański żywot miast przesiedlonych na przykładzie Lwowa. In: NICIEJA, Stanisław Sławomir. (ed.). Jałta z perspektywy pótwiecza. Materiały z konferencji naukowej zorganizowanej przez. Instytut Historii Uniwersytetu Opolskiego w dniach 25- 26 października 1994 r. Opole: Instytut Historii Uniwersytetu Opolskiego. ISBN 83-90367-11-4.

NICIEJA, Stanisław Sławomir (2009). Legenda Kresów Wschodnich Rzeczypospolitej. In: STAWARZ, Andrzej (ed.). Džiedziictwo i pamięć Kresów W schodnich Rzeczypospolitej. Materialy I Muzealnych Spotkań z Kresami. Warszawa: Muzeum Niepodległości. ISBN 978-83-87516-925.

NICIEJA, Stanisław Sławomir (2012). Kresowa Atlantyda. Historia i mitologia miast kresowych. Lwów, Stanisławów, Tarnopol, Bræeżany, Borysław, Opole: Wydawnictwo MS. ISBN 978-83-61915-270 .

PAŁASZEWSKA, Mirosława (2006). Pamiątki po Władysławie Zychu. In: Niepodlegtość i Pamieć, no 3 (24), pp. 347-362. ISSN 1427-1443.

PAŁASZEWSKA, Mirosława (2009). Kolekcja generała Romana Abrahama (1891-1976) w Muzeum Niepodległości. In: Niepodlegtość i Pamiéć, no 16/2 (30), pp. 319-344. ISSN $1427-$ 1443.

PRÓCHNIK, Adam (1919). Obrona Lwowa. Zamość: Zygmunt Pomarański i Spółka.

SACHA, Magdalena (2016). Fantomowe dziedzictwo? Różnice w muzealnej prezentacji dziedzictwa niemieckiego wschodu oraz polskich kresów - próba diagnozy. In: Rocznik Antropologii Historii, VI (9), pp. 147-170. ISSN 2084-1418.

SACHA, Magdalena Izabella (2019). Los niewidoczny? Kresy i kresowianie jako temat ekspozycji muzealnych po 1989 roku. In: Muzealnictwo, no 60, pp. 115-129. ISSN 0464-1086.

SIMON, Nina (2010). The participatory museum, Santa Cruz: CA. Museum 2.0.

SKOCZEK, Tadeusz, ŻYWEK, Lukasz (2014). Kolekecja Leopolis w zbiorach Muzeum Niepodległości. In: Niepodległość i Pamiéć, no 3-4 (47-48), pp. 285-293. ISSN 1427-1443.

SKOCZEK, Tadeusz (2015). Zamiast wstępu. In: Rocznik Kresony, no 1, pp. 5-6. ISSN 23916435. 
STAWARZ, Andrzej (1997). Słowo wstępne. In: Kresy W schodnie Ržeczypospolitej. Ziemi i ludžie, Warszawa: Muzeum Niepodległości. ISBN 83-903720-9-6.

ŚWIERZEWSKA, Olga (2018). „... krocząc wśród pocisków i ognia”. Lwów 1918-1919 w obrazkach Tadeusza Pobóg-Rossowskiego. In: Rocznike Kresowy, no 4, pp. 93-160. ISSN 2391-6435.

VERGO, Peter (2005). Milczący obiekt. In: POPCZYK, Maria (ed.). Muzeum sz̨tuki. Antologia. Kraków: Universitas, pp. 313-333. ISBN 07883-242-1060-2.

WALZ, Markus. The selection of cultural assets between research and plebiscite. Five museological points dealing with "collecting 2.0". In: MENSCH, Leontine Meijer, TIETMEYER, Elisabeth (eds.). Participative strategies in collecting the present. Berlin: Berliner Blatter, pp. 118-127.

WASYLKOWSKI, Janusz (1997). Notatki kolekcjonera. In: Kresy W schodnie Rzeczypospolitej. Ziemia i ludzie, Warszawa: Muzeum Niepodległości, 1997. ISBN 83-903720-9-6.

WIÓRKIEWICZ, Helena (1996). Witold Szolginia 1923-1996. In: Niepodlegtość i Pamiéć, no 2 (6), pp. 212-217. ISSN 1427-1443.

WIÓRKIEWICZ, Helena (1999). Kolekcja Leopolis Muzeum Niepodległości w Warszawie. In: Niepodlegtość i Pamiéć, no 1 (14), pp. 224-242. ISSN 1427-1443.

WIÓRKIEWICZ, Helena (1997). Wystawa. In: Kresy Wschodnie Rz̧eçypospolitej. Ziemi i ludżie, Warszawa: Muzeum Niepodległości. ISBN 83-903720-9-6.

WIÓRKIEWICZ, Helena (1999). Kresy Wschodnie Rzeczypospolitej. Ziemia i ludzie Wystawa w Muzeum Niepodległości w Warszawie. In: Niepodległość i Pamiéć, no 1 (14), pp. 247-264. ISSN 1427-1443.

WIÓRKIEWICZ, Helena (2000). Kolekcja Leopolis Muzeum Niepodległości w Warszawie. In: 10 lat Muzeum Niepodległości w Warszawie 1990-2000. Ksiega Pamiatkowa. Warszawa: Muzeum Niepodległości, pp. 127-142. ISBN 83-87516-19-8.

WIÓRKIEWICZ, Helena (2009). „Księgi pielgrzymstwa lwowskiego” w zbiorach Kolekcji Leopolis Muzeum Niepodległości w Warszawie. In: Dziedzictwo i pamię́ Kresón W schodnich Rzecsypospolitej. Materiały I Muzealnych Spotkań z Kresami. Warszawa: Muzeum Niepodległości, pp. 145-165. ISBN 978-83-87516-92-5.

WIÓRKIEWICZ, Helena (2013). Pamiątki lwowskiej rodziny Drexlerów w zborach Muzeum Niepodległości w Warszawie: dae Jadwigi Kern-Bałaty. In: Niepodległosć i Pamię́, no 3-4 (4344), pp. 305-367. ISSN 1427-1443.

WIÓRKIEWICZ, Helena (2017). II Muzealne Spotkania z Kresami. Z prac nad organizacja konferencji i przygotowaniem publikacji. In: Rocznik Kresowy, no 3, pp. 145-157. ISSN 23916435.

WIÓRKIEWICZ, Helena (2017). Pamiątki lwowskiej rodziny Drexlerów w zbiorach Muzeum Niepodległości w Warszawie. In: Dziedzictwo i pamiéc Kresón W schodnich Rzecsypospolitej. II Muzealne Spotkania z. Kresami, Warszawa: Wydawnictwo Muzeum Niepodległości, pp. 243299. ISBN 978-83-62235-47-6.

ZALASIŃSKA Katarzyna (2015). Muzealia, zbiory, eksponaty, kolekcja muzealna oraz zasoby muzeum - pojęcia podstawowe w muzealnictwie. In: STEC, Piotr. P.P. MANIURKA, Piotr, Paweł (eds.). Kolekcje $i$ zbiory muzealne. Problematyka prawna, Opole: Wydawnictwo Wydziału Teologicznego Uniwersytetu Opolskiego. ISBN 978-83 63950-61-3. 
ZAŁĘCZNY, Jolanta (2016). Pamiątki rodziny Klimowiczów w Kolekcji Leopolis Muzeum Niepodległości w Warszawie. In: Rocznik Muzeum Górnoślaskiego w Bytomiu, no 10, pp. 101114. ISSN 0068-4651.

ZAŁECZNY, Jolanta (2016). Smakowanie Lwowa. Ludwik i Władysław Zalewscy oraz ich cukiernia. In: Rocznik Kresowy, no 2, pp. 103-130. ISSN 2391-6435.

ZAŁECCZNY, Jolanta (2017). Szkic do lwowskich losów rodziny Mroczków. In: Rocznik Lwowski, pp. 105-147. ISSN 1230-0829.

ZAŁĘCZNY, Jolanta (2018). Kobiece troski, pasje i marzenia w listach Florentyny Skierskiej (1839-1890) do przyjaciółki Zofii Romanowiczówny. In: KITA, Jarosław, KORYBUTMARCINIAK, Maria (eds.). Życie prywatne Polaków w XIX wieku. t. VII. Prywatne swiaty zamknięte w listach, Łódź-Olsztyn: Wydawnictwo Uniwersytetu Lódzkiego, 2018, pp. 149_ 163. ISBN 978-83-8142-182-9.

ZAŁECCZNY, Jolanta (2019). Mieczysław Mroczek (1889-1939) - zwykły obrońca niezwykłego miasta. In: KOSESKI, Adam, SKOCZEK, Tadeusz. ZAŁECZNY, Jolanta (eds.), $W$ drugim szeregu. Bohaterowie walk o niepodległość, Warszawa-Pułtusk: Wydawnictwo Muzeum Niepodległości, Akademia Humanistyczna w Pułtusku, pp. 57-68. ISBN 978-65439-51-2.

ZAŁECZZNY, Jolanta (2020). Kresowe biografie wpisane w wojnę 1939 roku. In: FIC, Maciej. LUSEK, Joanna. ZALECZNY, Jolanta (eds.). A jednak wojna... Rok 1939 na Kresach Wschodnich $i$ Zachodnich, Bytom-Warszawa-Katowice: Muzeum Górnośląskiego, Muzeum Niepodległości, Uniwersytet Śląski, pp. 232-253. ISBN 978-83-66640-24-5.

ZAŁECZNY, Jolanta (2020). Maria Mazurkówna z Lwowa - sekretarka GTOZ, opiekunka przyrody i miłośniczka historii. In: Wrocławskie Studia Wschodnie, no 24, pp. 221-236. ISSN 0239-6661.

ŻYWEK, Lukasz (2016). Kolekcja Leopolis. List prof. Kazimierza Bartla do Rudolfa Kaczorowskiego, Lwów, 6.01.1922. In: Niepodległość i Pamię́, no 4, pp. 239-243. ISSN 14271443.

ŻYWEK, Lukasz (2017). Vilniana w zbiorach Muzeum Niepodległości w Warszawie, Warszawa: Wydawnictwo Muzeum Niepodległości, ISBN 978-83-62235-84-1.

ŻYWEK, Łukasz (2017). Włada Majewska - muza „Lwowskiej Fali”. In: GMITRUK, Janusz. JYDYCKI, Zbigniew. SKOCZEK, Tadeusz (eds.). Lwowianie w swiecie, Warszawa: Fundacja Polonia Semper Fidelis, pp. 199-207. ISBN 978-83-937112-3-9. 